$6-14-2020$

\title{
Rethinking the Reasoning of Verdugo-Urquidez
}

\author{
Alan Mygatt-Tauber \\ atauber@law.gwu.edu
}

Follow this and additional works at: https://www.repository.law.indiana.edu/ijlse

Part of the Law Commons

\section{Publication Citation}

Alan Mygatt-Tauber, Rethinking the Reasoning of Verdugo-Urquidez, 8 Ind. J.L. \& Soc. Equality 240 (2020).

This Article is brought to you for free and open access by the Law School Journals at Digital Repository @ Maurer Law. It has been accepted for inclusion in Indiana Journal of Law and Social Equality by an authorized editor of Digital Repository @ Maurer Law. For more information, please contact rvaughan@indiana.edu.

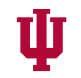

JEROME HALL LAW LIBRARY

INDIANA UNIVERSITY

Maurer School of Law
Blooming ton 


\title{
Rethinking the Reasoning of Verdugo-Urquidez
}

\author{
Alan Mygatt-Tauber*
}

\section{INTRODUCTION}

Since at least World War II, the Supreme Court has struggled with the question of whether aliens outside the United States could claim the protections of the Constitution. ${ }^{1}$ Since that time, the Court has only addressed the question in two instances: First, in its 1990 decision in United States $v$. Verdugo-Urquidez, ${ }^{2}$ where it held that the Warrant Clause of the Fourth Amendment ${ }^{3}$ does not apply to the search of an alien's home in Mexico. Second, in 2008's Boumediene v. Bush, where the Court held that the Suspension Clause of the Constitution ${ }^{4}$ did apply to alleged enemy combatants held in a Navy facility in Guantanamo Bay, Cuba. ${ }^{5}$

These two contrasting outcomes have been treated very differently by the lower courts. While lower courts have spent nearly thirty years expanding the reach of the Court's holding in Verdugo-Urquidez to circumstances and amendments beyond the core holding, ${ }^{6}$ they have taken an opposite approach in the decade since Boumediene, cabining that case to its specific facts. ${ }^{7}$ The question reached the Court again in the form of lawsuits over cross-border shootings by U.S. border patrol agents of Mexican citizens. ${ }^{8}$ Given the growing importance of the question, the conflicting precedent, and the complete lack of guidance provided by the Court's 1990 decision, the time is ripe for a reconsideration of the reasoning of VerdugoUrquidez.

* Adjunct Professor, Virginia Commonwealth University. Assistant Counsel, Naval Facilities Engineering Command, Northwest. The views expressed in this article are solely those of the author and do not reflect the views of the Department of the Navy. I would like to thank Professor Orin Kerr and James Fallows Tierney for their comments on earlier drafts of this article, as well as Professor Emeritus Ira "Chip" Lupu, formerly of the George Washington University School of Law, for pointers on incorporating rights via the Due Process Clause. Any mistakes are mine alone.

1 Johnson v. Eisentrager, 339 U.S. 763 (1950) (holding that U.S. courts have no jurisdiction over prisoners of war detained in Germany).

2 United States v. Verdugo-Urquidez, 494 U.S. 259 (1990).

$3 \quad$ U.S. Const. amend. IV (“[N]o Warrants shall issue, but upon probable cause, supported by Oath or affirmation, and particularly describing the place to be searched, and the persons or things to be seized.").

4 U.S. Const. art. I, § 9, cl. 2 ("The Privilege of the Writ of Habeas Corpus shall not be suspended, unless when in Cases of Rebellion or Invasion the public Safety may require it.").

$5 \quad$ Boumediene v. Bush, 553 U.S. 723 (2008).

6 See cases cited infra notes 62-107.

$7 \quad$ See, e.g., Al Maqaleh v. Hagel, 738 F.3d 312, 336 n.16 (D.C. Cir. 2013), vacated on other grounds by Amanatullah v. Obama, 575 U.S. 908 (2015); Kiyemba v. Obama, 555 F.3d 1022, 1032 (D.C. Cir. 2009) vacated and remanded sub nom. Kiyemba v. Obama, 559 U.S. 131 (2010).

8 See, e.g., Hernandez v. Mesa, 885 F.3d 811 (5th Cir. 2018), cert. granted 139 S. Ct. 2636 (2019); Rodriguez v. Swartz, 899 F.3d 719 (9th Cir. 2018). While the Court has so far focused on the question of whether a remedy is available, it is only a matter of time before the antecedent question of whether aliens have rights to press in U.S. courts finds its way back. Justice Ginsburg specifically mentioned Verdugo-Urquidez in her dissent. Hernandez v. Mesa, 140 S. Ct. 735, 754 n.1 (2020) (Ginsburg, J., dissenting). 
Verdugo-Urquidez fails on a number of levels. Almost immediately, the opinion received criticism from those in academia, ${ }^{9}$ which has largely been borne out over the subsequent decades. ${ }^{10}$ It sets up an open-ended and largely undefined test, which provides no guidance to lower courts. ${ }^{11}$ As a result, lower courts have struggled to apply Verdugo-Urquidez's reasoning to cases involving the Fourth Amendment, which it purported to address. Moreover, the cramped analysis fails to offer guidance about the application of other constitutional guarantees that do not share the language and structure of the Fourth Amendment. But this has not prevented lower courts from importing the Court's analysis to clauses where it is wholly inapplicable. ${ }^{12}$

The solution to these twin problems lies with two potential solutions. First, I offer an outline that courts applying Verdugo-Urquidez can follow to determine when an alien's connections to the United States become substantial enough that the alien may claim the protection of the Fourth Amendment. I argue that courts should look at both the quality and quantity of connections, with a recognition that certain connections, by their nature, are more substantial than others. I also argue that the age of the connection matters. Older, maintained connections are more substantial than newer or fleeting ones. I also argue that courts should apply a presumption that stale connections are no longer valid. But easier than merely trying to place guideposts around the substantial connections test propounded by Verdugo-Urquidez is to craft a bright line rule that, anytime a search is conducted by agents of the United States, the protections of the Fourth Amendment should apply.

I argue for two doctrinally sound ways to extend the protections of the Fourth Amendment to aliens abroad: 1) offering the same protection offered to US citizens when US agents conduct, or substantially participate in, searches abroad; and 2) extending it as a component of due process. I then offer a practical means of enforcing the Amendment, grounded in an earlier "joint venture" test utilized by lower courts both before and after Verdugo-Urquidez. Under this test, courts first examine whether United States agents played a substantial role in the extraterritorial search. If they did not, then the Fourth Amendment does not apply. If, however, those agents did substantially participate in an extraterritorial search, then the Fourth Amendment's reasonableness requirement should travel with them. The only additional exception would be cases where the conduct of foreign

9 See Douglas I. Koff, Post-Verdugo-Urquidez: The Sufficient Connection Test - Substantially Ambiguous, Substantially Unworkable, 25 Colum. Hum. RTS. L. Rev. 435 (1994); Janet E. Mitchell, The Selective Application of the Fourth Amendment: United States v. Verdugo-Urquidez, 41 CATH. U.L. Rev. 289 (1991); Mary Lynn Nicholas, United States v. Verdugo-Urquidez: Restricting the Borders of the Fourth Amendment, 14 Fordham Int'L L. Rev. 267 (1990); Mindy Ann Oppenheim, United States v. Verdugo-Urquidez: Hands Across the Border - The Long Reach of United States Agents Abroad, and the Short Reach of the Fourth Amendment, 17 Brook. J. InT'L L. 617 (1991); Leonard X. Rosenberg, Fourth Amendment - Search and Seizure of Property Abroad: Erosion of the Rights of Aliens: United States v. Verdugo-Urquidez, $110 \mathrm{~S}$. Ct. 1056 (1990), 81 J. CRIM. L. \& CRIMINOLOGY 779 (1991).

10 See infra notes $62-83$ and accompanying text.

11 See infra Section III.A.

12 See infra Section III.B. 
agents is so egregious that it "shocks the judicial conscience." In those cases, even if there were no participation by U.S. agents, U.S. courts should refuse to admit evidence of criminal activity.

\section{UNITED STATES V. VERDUGO-URQUIDEZ AND THE EXTRATERRITORIAL WARRANT REQUIREMENT}

Rene Martin Verdugo-Urquidez was a citizen and resident of Mexico. ${ }^{13}$ The U.S. Drug Enforcement Agency suspected him of being one of the leaders of a large and violent drug cartel in Mexico, responsible for smuggling marijuana into the United States, as well as participating in the kidnapping, torture, and murder of a DEA special agent. ${ }^{14}$ In January 1986, after discussions with U.S. Marshalls, Mexican police apprehended Verdugo-Urquidez and delivered him to the United States Border Patrol station in Calexico, California, where he was arrested and transferred to a correctional facility in San Diego to await trial. ${ }^{15}$

Following Verdugo-Urquidez's arrest, DEA agents decided to arrange for a search of his residences located in Mexicali and San Felipe, Mexico. ${ }^{16}$ U.S. agents, joined by officers of the Mexican Federal Judicial Police (MFJP), searched VerdugoUrquidez's home and seized documents, including a tally sheet believed to show quantities of marijuana smuggled into the United States. ${ }^{17}$

Verdugo-Urquidez moved to suppress the evidence seized in his Mexican residences, and the District Court granted the motion, concluding that the Fourth Amendment applied to the searches and the DEA agents failed to justify the search without a warrant. ${ }^{18}$ The Ninth Circuit, in a divided opinion, affirmed the decision. ${ }^{19}$ On appeal, the Court was asked to determine whether the Fourth Amendment applied to an extraterritorial search of a non-U.S. citizen. The Court held that it did not.

After reciting this factual and procedural history, the majority opinion held that, unlike the Fifth Amendment, a violation of the Fourth Amendment is "fully accomplished" at the time of the unreasonable government intrusion. ${ }^{20}$ Under the majority's approach, the violation occurs at the time of the search. Thus, any constitutional violation occurred solely in Mexico. ${ }^{21}$

The Court then turned to the text of the Fourth Amendment:

13 United States v. Verdugo-Urquidez, 494 U.S. 259, 262 (1990).

14 Id. Verdugo-Urquidez was subsequently convicted of the murder in a separate prosecution. See United States v. Verdugo-Urquidez, 29 F.3d 637 (Table), 1994 WL 279226 (9th Cir. Aug. 5, 1994).

15494 U.S. at 262.

$16 \quad I d$.

17 Id. at 262-63.

18 Id. at 263.

19 United States v. Verdugo-Urquidez, 856 F.2d 1214 (9th Cir. 1988).

20 Verdugo-Urquidez, 494 U.S. at 264 (first citing United States v. Calandra, 414 U.S. 338 , 354 (1974); then citing United States v. Leon, 468 U.S. 897, 906 (1984)).

21494 U.S. at 264. 
The right of the people to be secure in their persons, houses, papers, and effects, against unreasonable searches and seizures, shall not be violated, and no Warrants shall issue, but upon probable cause, supported by Oath or affirmation, and particularly describing the place to be searched, and the persons or things to be seized. ${ }^{22}$

The majority adopted the logic of Chief Judge Wallace's dissent in the Ninth Circuit, finding that the term "the people" was a "term of art employed in select parts of the Constitution." 23 The Court noted that, in addition to the Fourth Amendment, the phrase appears in the Preamble, the Second Amendment, the Ninth and Tenth Amendments, and the First Amendment's protections of the rights to assembly and petition, as well as in Article I, Section 2, clause 2. ${ }^{24}$ The Court acknowledged this was not conclusive, but believed it suggested that "the people" protected by these Amendments were "a class of persons who are part of a national community or who have otherwise developed sufficient connection with this country to be considered part of that community." 25 The Court concluded that "the purpose of the Fourth Amendment was to protect the people of the United States against arbitrary action by their own government; it was never suggested that the provision was intended to restrain the actions of the Federal Government against aliens outside of the United States territory." 26

Looking to precedent, the Court invoked the Insular Cases, a series of decisions at the turn of the twentieth century collectively holding that constitutional provisions did not apply uniformly to territory over which the United States is sovereign, ${ }^{27}$ unless that territory is destined for eventual statehood. ${ }^{28}$ Only rights determined to be "fundamental" apply in these "unincorporated" territories. ${ }^{29}$

22 U.S. Const. amend. IV.

23494 U.S. at 265.

24 Id. ("The House of Representatives shall be composed of Members chosen every second Year by the People of the several States.").

25 Id. (contrasting with the language in the Fifth and Sixth Amendments, which use the terms "person" and "accused," respectively).

$26 \quad$ Id. at 266.

27 Id. at 268 (citing the Insular Cases: Balzac v. Porto Rico, 258 U.S. 298 (1922) (Sixth Amendment right to a jury trial inapplicable in Puerto Rico); Ocampo v. United States, 234 U.S. 91 (1914) (Fifth Amendment grand jury provision inapplicable in Philippines); Dorr v. United States, 195 U.S. 138 (1904) (jury trial provision inapplicable in Philippines); Hawaii v. Mankichi, 190 U.S. 197 (1903) (provisions on indictment by grand jury and jury trial inapplicable in Hawaii); and Downes v. Bidwell, 182 U.S. 244 (1901) (Uniform Duty Clause not applicable to Puerto Rico)). For more on the Insular Cases, as well as a critique, see generally Alan Tauber, The Empire Forgotten: The Application of the Bill of Rights to U.S. Territories, 57 CASE W. RES. L. REV. 147, 154-73 (2006).

28 Hawaii v. Mankichi stands out in that Hawaii later did become a state. However, in 1903, when Mankichi was decided, that was hardly self-evident in the same way that territory in the continental United States was viewed as destined for statehood. Additionally, the "territorial incorporation doctrine," created by Justice White in several early concurrences in the Insular Cases did not achieve majority recognition until 1922 in Balzac v. Porto Rico, 258 U.S. Today, the territories falling into this category are Puerto Rico, Guam, the U.S. Virgin Islands, the Commonwealth of the Northern Mariana Islands, and American Samoa.

29 Verdugo-Urquidez, 494 U.S. at 268 (distinguishing, in the context of the Insular Cases, "fundamental" rights from "procedural" rights; while the language is similar to that used in debates over incorporation of rights to the States via the Fourteenth Amendment, the rights deemed to be "fundamental" are different); 
According to the Court, if U.S. citizens in unincorporated U.S. territories are not entitled to all constitutional rights, the case for aliens in foreign nations is even weaker. ${ }^{30}$

The majority then noted that the Court has rejected application of the far broader Fifth Amendment to aliens outside the sovereign territory of the United States in Johnson v. Eisentrager. ${ }^{31}$ While Eisentrager acknowledged that the alien "has been accorded a generous and ascending scale of rights as he increases his identity with our society[,]"32 the majority described the Court's rejection of the extraterritorial application of the Fifth Amendment as "emphatic:"33

Such extraterritorial application of organic law would have been so significant an innovation in the practice of governments that, if intended or apprehended, it could scarcely have failed to excite contemporary comment. Not one word can be cited. No decision of this Court supports such a view. None of the learned commentators on our Constitution has even hinted at it. The practice of every modern government is opposed to it. ${ }^{34}$

Given this rejection of the Fifth Amendment, which uses the nearly universal term "person," the Court believed a similar fate should befall the Fourth Amendment, which applies only to "the people." 35

In support of his claim that the seized evidence should be suppressed, Verdugo-Urquidez relied on a series of cases holding that aliens enjoy constitutional rights. ${ }^{36}$ The Court held that this series of cases "establish[ed] only that aliens receive constitutional protections when they have come within the territory of the United States and [have] developed substantial connections with this country." 37 Verdugo-Urquidez had no prior significant connections with the United States, and his status at the time of the search-lawful but involuntary-also did not create a substantial connection. ${ }^{38} \mathrm{He}$ had been in United States custody only a few days when the search was executed, and the majority did not think the applicability of

see also Edward C. Carter, III, The Extra-Territorial Reach of the Privilege Against Self Incrimination or Does the Privilege "Follow the Flag?”, 25 S. Ill. U. L.J. 313, 320-21 (2001); Tauber, supra note 27, at 166-68.

30 Verdugo-Urquidez, 494 U.S. at 268.

31 Johnson v. Eisentrager, 339 U.S. 763, 785 (1950).

32 Id. at 770.

33 Verdugo-Urquidez, 494 U.S. at 269.

34 Eisentrager, 339 U.S. at 784-85 (internal citations omitted).

35 Verdugo-Urquidez, 494 U.S. at 269.

36 See also Plyler v. Doe, 457 U.S. 202, 211-12 (1982) (undocumented immigrants protected by Equal Protection Clause); Kwong Hai Chew v. Colding, 344 U.S. 590, 596 (1953) (resident alien is a "person" within the meaning of the Fifth Amendment); Bridges v. Wixon, 326 U.S. 135, 148 (1945) (resident aliens have certain First Amendment rights); Russian Volunteer Fleet v. United States, 282 U.S. 481, 489 (1931) (aliens entitled to protection of the Just Compensation Clause of the Fifth Amendment); Wong Wing v. United States, 163 U.S. 228, 238 (1896) (resident aliens entitled to Fifth and Sixth Amendment rights); Yick Wo v. Hopkins, 118 U.S. 356, 369 (1886) (resident aliens protected by the Fourteenth Amendment).

37 Verdugo-Urquidez, 494 U.S. at 271.

$38 \quad I d$. 
the Fourth Amendment should turn on the chance that the custodian of the nonresident alien owner had or had not transported him to the United States at the time of the search. ${ }^{39}$

The Court ended its opinion with a brief discussion of the negative practical consequences of adopting Verdugo-Urquidez's position. According to the Court, applying the Fourth Amendment overseas would risk interfering with national security and disrupting the ability of the political branches to respond to foreign crises ${ }^{40}$ More alarming to the Court, if Verdugo-Urquidez's position carried the day, aliens with no attachment to the United States might be entitled to damages actions against federal agents for violations of the Fourth Amendment in foreign countries or international waters. ${ }^{41}$ While acknowledging that there may be limits to such remedies, the Court still felt that applying the Fourth Amendment abroad would plunge legislative and executive branch employees into a "sea of uncertainty" as to what might be reasonable in conducting searches and seizures abroad. ${ }^{42}$ Therefore, based on the text, history, precedent, and practical concerns, the Court concluded that if there are to be limits on searches and seizures abroad, they must be imposed by the political branches. ${ }^{43}$

\section{Problems With Verdugo-URquidez's ReAsoning}

Prevailing practice in the lower courts has demonstrated that, as predicted by scholars when the decision came out, the rule from Verdugo-Urquidez provides so little guidance about the "substantial connections" test that it creates the very problem it was trying to solve. One of the key practical concerns raised by the Court was that law enforcement officers would be plunged into a "sea of uncertainty." But as history has shown, the Court's test causes just as much uncertainty in searches occurring abroad, and brings that sea to our own shores, complicating the question for domestic searches as well. As this part will demonstrate, the Verdugo-Urquidez "substantial connections" test suffers from two major problems: 1) it provides no guidance to lower courts on important matters; and 2) as a result, its reasoning has been applied to constitutional provisions that are not analogous to the Fourth Amendment, sowing greater confusion in the law.

In his dissent, Justice Brennan predicted some of the problems encountered by the lower courts, ${ }^{44}$ as explored in this section. Surprisingly, the majority failed to directly engage with his criticisms. Justice Brennan took issue with the test laid out

$39 \quad$ Id. at 272.

$40 \quad$ See id. at 273-74.

41 Id. at 274 (first citing Bivens v. Six Unknown Fed. Narcotics Agents, 403 U.S. 388 (1971); then citing Graham v. Connor, 490 U.S. 386 (1989); then citing Tennessee v. Garner, 471 U.S. 1 (1985)).

$42 \quad I d$.

$43 \quad I d$. at 275.

44 Verdugo-Urquidez, 494 U.S. at 279-97 (Brennan, J., dissenting). These criticisms fall into four broad categories: 1) that the Fourth Amendment is the "unavoidable correlative" of the Constitution's powers to criminalize behavior; 2) criticisms of the test laid out by the majority; 3) issues with the majority's treatment of the cases it relied upon; and 4) disagreement with the practical concerns laid out by the majority and Justice Kennedy's concurrence. $I d$. 
by the majority. He noted that, even within the majority opinion, the contours of the test shift and lack definition, sometimes appearing to require physical presence, while at others a voluntary connection. ${ }^{45} \mathrm{He}$ also observed that the Court failed to address what the Fourth Amendment requires should an alien actually have substantial voluntary connections. ${ }^{46}$ Finally, he took the majority to task for failing to note that Verdugo-Urquidez had one of the strongest possible connections-he was being held in the physical custody of the United States. ${ }^{47}$

There are other flaws with the majority's reasoning that Justice Brennan does not address. For example, the Court purports to interpret the term "the people," but this term applies to unreasonable searches, not the warrant requirement. Thus, relying on the term of art "the people" to limit the reach of the Warrant Clause is logically inconsistent with the wording of the Fourth Amendment. Furthermore, some of the practical issues raised by the Court are based entirely on concerns about applying the warrant requirement and its demands for probable cause. ${ }^{48}$ Because the term "the people" does not modify the Warrant Clause, those practical concerns are focused solely on the application of a warrant outside U.S. territory and do not support the Court's finding that "the people" are limited to U.S. citizens and those with substantial ties to the United States. ${ }^{49}$

\section{A. The "Substantial Connections" Test Provides No Guidance to Lower Courts}

Justice Brennan, in his dissent, identifies the lack of guidance and shifting requirements the majority opinion identifies. ${ }^{50}$ The majority never provides any direction as to the type or number of connections an alien must have to be considered one of "the people" entitled to the protection of the Fourth Amendment. ${ }^{51}$ The majority requires an undefined "sufficient connection" which, at times, is described as physical presence within the United States and the establishment of "substantial connections." 52 Elsewhere, the Court suggests that an alien's presence

$45 \quad$ Id. at $282-83$.

$46 \quad$ Id. at 283 n.7.

47 Id. at $283-84$.

48 Id. at 274 (majority opinion) ("Indeed, the Court of Appeals held that absent exigent circumstances, United States agents could not effect a 'search or seizure' for law enforcement purposes in a foreign country without first obtaining a warrant, which would be a dead letter outside the United States, from a magistrate in this country. Even if no warrant were required, American agents would have to articulate specific facts giving them probable cause to undertake a search or seizure if they wished to comply with the Fourth Amendment as conceived by the Court of Appeals.")

49 As discussed infra, these practical concerns, and those raised by Justice Kennedy in his concurrence, can be better addressed without gutting the protections of the Fourth Amendment for aliens abroad.

50 See Verdugo-Urquidez, 494 U.S. at 282-83 (Brennan, J., dissenting).

51 Scholars noted this problem in the immediate wake of Verdugo-Urquidez. See Oppenheim, supra note 9, at 638; Nicholas, supra note 9, at 295, 299, 306; and Koff, supra note 9, at 461, 471-72.

52 Verdugo-Urquidez, 494 U.S. at 271. Here, however, even Justice Brennan appears to misread the majority. The opinion, after listing a number of cases in which aliens have been found to have rights under the Constitution states that "[t]hese cases, however, establish only that aliens receive constitutional protections when they have come within the territory of the United States and developed substantial connections with the country." Id. The placement of that "only" is key. The majority does not state that only those who have 
must be voluntary ${ }^{53}$ and that he must have undertaken some societal obligations. ${ }^{54}$ The only thing the majority makes clear is that an alien who had not been to the United States before, and whose presence was of short duration and solely the result of an arrest, cannot claim the protections of the Fourth Amendment. 55

This confusion has been demonstrated by the decisions of lower courts, which have struggled to apply Verdugo-Urquidez. ${ }^{56}$ In cases with facts similar to VerdugoUrquidez, the application of the substantial connections test has been straightforward and easily applied. For example, the Eleventh Circuit, ${ }^{57}$ First Circuit, ${ }^{58}$ and Ninth Circuit ${ }^{59}$ have all followed the Supreme Court's guidance and held that searches of non-U.S. citizens conducted outside the United States are not covered by the Fourth Amendment when the alien has no ties to the United States. District court cases have also followed the plain reading of Verdugo-Urquidez. ${ }^{60}$ This relatively straightforward application of Verdugo-Urquidez, however, appears to be fairly rare.

When lower courts have been faced with claims by aliens that they possess the necessary connections to the United States, lower courts have struggled to come up with a consistent determination of what constitutes a substantial connection. ${ }^{61}$ Indeed, no court has purported to come up with a litmus test, leaving each individual determination to an ad hoc process. Law enforcement, defense attorneys,

such connections and physical presence can claim the protection of the Constitution. Rather, its use of only limits what the cases hold, not to whom they apply. For more on the importance of the placement of the word "only" in the sentence see Nat'l Counsel of Resistance of Iran v. Dep't of State, 251 F.3d 192, 201-02 (D.C. Cir. 2001).

53 Verdugo-Urquidez, 494 U.S. at 282.

54 Id. at 273 (citing INS v. Lopez-Mendoza, 468 U.S. 1032 (1984)) (asserting that the undocumented immigrants had "presumably" accepted such obligations).

55 Also unexplained is why Verdugo-Urquidez's alleged criminal activities, which involved the importation of a substantial amount of narcotics, would not satisfy this requirement. No one has ever suggested that criminals are not among "the people" of the United States. Indeed, it would be an odd argument, since the vast majority of cases in which the Fourth Amendment would apply would involve criminal activities. Moreover, the Fourth Amendment has been found to apply to aliens who have entered the United States illegally. See, e.g., Almeida-Sanchez v. United States, 413 U.S. 266, 274 (1973) (holding that the Fourth Amendment applied to the search of a vehicle driven by an alien who had entered the United States illegally). If their connection is voluntary for purposes of the Fourth Amendment, it is unclear why VerdugoUrquidez's connections would not be. True, his presence was involuntary, but presence in the United States is not a pre-requisite to claiming the protection of the Fourth Amendment. Numerous courts have recognized that the Fourth Amendment applies to U.S. citizens abroad. See infra note 152. And the Court did not distinguish between citizens and aliens with substantial connections-both groups were among "the people."

56 See Koff, supra note 9, at 456-71 for an analysis of the early circuit confusion applying the test.

57 United States v. Emmanuel, 565 F.3d 1324 (11th Cir. 2009) (considering the wiretap of Bahamian national in the Bahamas).

58 United States v. Vilches-Navarrete, 523 F.3d 1 (1st Cir. 2008) (considering the search of alien vessel whose presence in U.S. was based on need for safe search of vessel).

59 United States v. Zakharov, 468 F.3d 1171 (9th Cir. 2006) (considering an alien arrested after search of vessel on the high seas).

60 See, e.g., United States v. Gomez Castrillon, 2007 WL 2398810 (S.D.N.Y. Aug. 15, 2007) (finding an alien with no prior connections to the U.S. has no Fourth Amendment rights regarding wiretaps in Colombia).

61 See Koff, supra note 9, at 456-71. 
and courts themselves are left adrift in a sea of uncertainty about whether a particular search requires a warrant. In some circuits, aliens with seemingly significant ties are found to have no substantial connections, while in others with seemingly ephemeral or fleeting ties are found to be protected by the Fourth Amendment. Even within circuits, different courts have come to radically different conclusions.

The Ninth Circuit, for example, found that being a student at an American university, even if outside the United States at the time of the challenge, established substantial connections. ${ }^{62}$ On the other hand, the Northern District of California determined that a man with twelve years of residency, marriage to a resident alien, a four-year-old American citizen child, a California driver's license, payment of traffic tickets, ten years living in California communities, and payment of sales taxes established familial ties, but not substantial connections with the United States. 63

The D.C. Circuit has held that a non-profit organization with an office and a small bank account in the United States has established substantial connections. ${ }^{64}$ Meanwhile, the District Court for the District of Columbia held that regular visits to the United States to visit an ill daughter and granddaughter did not rise to the level of a substantial connection. ${ }^{65}$

A district court in Texas found that an alien who made "regular trips" into the United States each month and had been issued a "border crossing card" had established such connections. ${ }^{66}$ But a Wisconsin district court found that regular visits, telephone calls and online chats with over a dozen family members and friends, numerous visits to family over fifteen years, numerous business contacts, and other assorted connections did not satisfy Verdugo-Urquidez. ${ }^{67}$

There is so little guidance provided to lower courts that some courts have split within the same decision as to whether an alien's ties are substantial. In United States $v$. Portillo-Munoz, two judges believed that having a job, paying rent for eighteen months, and supporting a family did not provide substantial connections. ${ }^{68}$ Judge Dennis dissented, finding that these same ties met the Verdugo-Urquidez test. ${ }^{9}$ The Court of Appeals for the Armed Forces also faced a similar split in United States $v$. Ali. ${ }^{70}$ The majority found that a week of pre-

62 Ibrahim v. United States Dep't of Homeland Security, 669 F.3d 983 (9th Cir. 2012).

63 United States v. Guitterez, 1997 U.S. Dist. LEXIS 16446 (N.D. Cal. Oct. 16, 1997), vacated, 983 F.Supp. 905 (N.D. Cal. 1998), rev'd without opinion 203 F.3d 833 (9th Cir. 1999). But see De Leon v. Reno, 1998 WL 289321 (N.D. Cal. March 26, 1998) (finding that four years' residency, including more than a year since previous illegal entry established substantial connections). This also ignores the fact that the searches in Guitterez and De Leon were domestic, rather than foreign searches, an issue discussed in more detail below.

64 Nat'l Council of Resistance of Iran v. Dep't of State, 251 F.3d 192 (D.C. Cir. 2001).

65 American Immigration Lawyer Ass'n v. Reno, 18 F. Supp. 2 d 38 (D.D.C. 1998).

66 Martinez-Aguero v. Gonzales, 2005 U.S. Dist. LEXIS 2412 *65 (W.D. Tex. Feb. 2, 2005).

67 United States v. Baboolal, 2006 WL 1674480 (E.D. Wis. June 16, 2006).

$68 \quad 643$ F.3d 437 (5th Cir. 2011).

$69 I d$. at 442-43 (Dennis, J., concurring in part, dissenting in part).

7071 M.J. 256 (C.A.A.F. 2012). 
deployment training at Fort Benning, Georgia, and employment with a U.S. contractor outside the United States did not establish substantial connections. The concurrence held that service with the armed forces in the uniform of the United States was a substantial connection. ${ }^{71}$

This is to say nothing of the fact that many courts have applied the substantial connections test to searches that take place within the territorial boundaries of the United States. Nothing in Verdugo-Urquidez indicated that its analysis should apply to a domestic search. However, courts are divided even on this seemingly easy question. The Northern District of California has limited Verdugo-Urquidez to its facts and held that it is inappropriate to look for substantial connections when an alien is within the U.S.72 The District of Arizona, however, still relied on the substantial connections test to judge a challenge to a warrant executed in the United States. ${ }^{73}$ As part of this confusion regarding Verdugo-Urquidez's application to domestic searches, courts have differed on whether undocumented aliens can claim to have substantial connections at all. ${ }^{74}$ The Northern District of California has held that such individuals can establish substantial connections. ${ }^{75} \mathrm{~A}$ district court in Utah also held that such individuals can establish substantial connections. ${ }^{76}$ However, other courts have held that undocumented immigrants can never claim the protections of the Constitution. ${ }^{77}$

Judges have further divided on whether the so-called "entry fiction" operates to prevent application of the Fourth Amendment to aliens who are physically present in the United States, but have not been admitted. ${ }^{78}$ Three cases have found that the entry fiction does not apply to excessive force claims under the Fourth Amendment, because mere presence is enough of a connection. ${ }^{79}$ But at least one

71 Id. at 277-78 (Baker, J., concurring).

72 United States v. Guitterez, 983 F. Supp. 905 (N.D. Cal. 1998), rev'd without opinion, 203 F.3d 833 (9th Cir. 1999). The Court sua sponte reconsidered its earlier decision in United States v. Guitterez, 1997 U.S. Dist. LEXIS 16446 (N.D. Cal. Oct. 14, 1997), in which it had determined Mr. Guitterez lacked substantial connections.

73 United States v. Alahmedalabdaloklah, 2017 U.S. Dist. LEXIS 102740 (D. Ariz. July 3, 2017) (denying challenge to 2703(d) requirements for court order because the storage of the content of electronic communications on servers located in the United States cannot justify extending Fourth Amendment protections to a person who does not have substantial connections to the United States).

74 Scholars predicted this outcome shortly after Verdugo-Urquidez was decided. Nicholas, supra note 9, at 308.

75 See De Leon, 1998 WL 289321.

76 United States v. Atienzo, 2005 WL 3334758 (D. Utah Dec. 7, 2005).

77 See, e.g., United States v. Boffil-Rivera, 2008 U.S. Dist. LEXIS 84633 (S.D. Fla. Aug. 12, 2008).

78 The "entry fiction," created by Shaughnessy v. Mezei, 345 U.S. 206 (1953), holds that "an alien on the threshold of initial entry" stands on a different footing than one who has entered the United States, either legally or illegally, even if the unadmitted alien is physically present in the United States. Under this fiction, the arrival at a port of entry, although physically within the United States, does not qualify as entering the country. Thus, a search of an alien would be considered extraterritorial. This status follows the alien even if they are "paroled" into the United States pending determination of admissibility. See Leng May Ma v. Barber, 357 U.S. 185, 187 (1958).

79 United States v. Parker, 2016 U.S. Dist. LEXIS 4764 (N.D. Ala. Jan. 13, 2016); Castro v. Cabrera, 742 F.3d 595 (5th Cir. 2014); Martinez-Aguero v. Gonzales, 459 F.3d 618 (5th Cir. 2006). 
judge has opined that the entry fiction applies and treats aliens as if they are not present in the United States. ${ }^{80}$

Finally, courts have divided over whether the term "the people," as discussed in Verdugo-Urquidez, is the same for all purposes. For example, two courts have found that the term as used in the Fourth Amendment covers a different group than the identical term in the Second Amendment. ${ }^{81}$ This runs directly counter to the majority's textual analysis, which depended on the identical nature of the term to justify denying aliens the protection of the Fourth Amendment. ${ }^{82}$ Other courts, however, have found that the use of the phrase in both amendments is identical; thus, the substantial connections test governs whether an alien has rights under the Second Amendment. ${ }^{83}$

Over time, the majority's reasoning in Verdugo-Urquidez has proven to provide little guidance to lower courts, just as Justice Brennan predicted in his dissent. Litigants, law enforcement officers, and judges lack any method to determine if a particular set of connections will be sufficient to warrant the protections of the Fourth Amendment. For law enforcement officers, the lack of an ex ante rule risks the success of a criminal prosecution. If they judge an alien's ties to be insufficient, and fail to seek a warrant, they could see valuable evidence suppressed. For litigants, the lack of an ex post standard makes trial and appeal strategies uncertain at best. It is not clear if courts will entertain a motion to suppress even in a case involving a domestic search. And for judges, the lack of guidance leaves them adrift, unable to determine if their decisions on the necessity of a warrant, the reasonableness of a search, or lack thereof, will be upheld on appeal. The law demands more.

\section{B. The "Substantial Connections" Test Has Been Repeatedly Applied in Unintended Areas Without Sufficient Justification}

Another reason to reconsider the reasoning of the majority's opinion in Verdugo-Urquidez is that it has been repeatedly extended to other amendments by lower courts without a textual basis. ${ }^{84}$ While the Court may have failed to provide any clear guidance about what constitutes "substantial connections," it was clear

80 Rosales-Garcia v. Holland, 238 F.3d 704, 735 (6th Cir. 2001) (Rice, J., dissenting).

81 United States v. Meza, 2014 U.S. Dist. LEXIS 50485 (E.D. Wis. Feb. 25, 2014) (finding that the Second Amendment did not apply to aliens "illegally present" in the United States); United States v. PortilloMunoz, 643 F.3d 437, 440 (5th Cir. 2011) ("Moreover, even if there were precedent for the proposition that illegal aliens generally are covered by the Fourth Amendment, we do not find that the use of 'the people' in both the Second and the Fourth Amendment mandates a holding that the two amendments cover exactly the same groups of people.").

82 If the term "the people" can mean different things in different places within the Constitution, then its use in the Preamble and Article I provides no guidance whatsoever in interpreting the meaning of the Fourth Amendment. In that case, another argument made by Justice Brennan, that the term was a rhetorical flourish to contrast "the people" with "the government," becomes much more persuasive.

83 See, e.g., United States v. Mesa-Rodriguez, 798 F.3d 664 (7th Cir. 2015) (finding that the Second and Fourth Amendments should be read together and that twenty years presence, attending school, close relationships with family and others, and sporadic employment constituted substantial connections).

84 See infra notes 87-95 discussion and accompanying text. 
that the reason they were needed is due to the specific language of the Fourth Amendment. Thus, a proper extension of Verdugo-Urquidez would be limited to constitutional provisions which contain the words "the people," since it was this language which caused the Court to limit the Fourth Amendment's reach. ${ }^{85}$ However, many lower courts have applied the "substantial connections" test to constitutional provisions which have nothing in common with the Fourth Amendment and which do not invoke the term "the people." 86

Whatever one thinks about Chief Justice Rehnquist's textual exegesis, it was a key component to the reasoning of the Court, since it was the basis of the "substantial connections" test. Verdugo-Urquidez was not entitled to the protections of the Fourth Amendment because he was not among "the people" whose rights the amendment was designed to protect. One would expect that the reasoning of Verdugo-Urquidez would only apply to those Amendments which use that term. ${ }^{87}$ But lower courts have treated the "substantial connections" test as the test for the extraterritorial application of the Constitution, applying it to provisions which nowhere mention "the people," including to the Fifth and Sixth Amendments, which not only use broader terms, such as "person" and "the accused," but which the majority specifically differentiated for that reason.

Despite the Court's reliance on the specific text of the Fourth Amendment, lower courts have applied the logic of Verdugo-Urquidez to claims under the Due Process Clauses of the Fifth ${ }^{88}$ and Fourteenth ${ }^{89}$ Amendments, the Takings Clause of the Fifth Amendment, ${ }^{90}$ the right to jury trial under the Sixth ${ }^{91}$ and Seventh ${ }^{92}$ Amendments, the Equal Protection Clause of the Fourteenth Amendment, ${ }^{93}$ and Article I, Section 9 Clauses $2^{94}$ and $3^{95}$ of the Constitution. Indeed, it is safe to say that the logic of Verdugo-Urquidez has been applied incorrectly almost as often as it has been properly used. ${ }^{96}$ Courts have identified a variety of reasons to extend the

85 At least one scholar predicted that lower courts may "greatly expand the holding" beyond the parameters set by the Court. Oppenheimer, supra note 9 , at 622.

86 See infra notes 87-95.

87 As noted earlier, this would include portions of the First, Second, Fourth, Ninth, and Tenth Amendments.

88 Al-Marri v. Wright, 487 F.3d 160 (4th Cir. 2007); Do Rosario Veiga v. World Meteorological Org., 568 F. Supp. 2d 367 (S.D.N.Y. 2008); United States v. Ali, 71 M.J. 256 (C.A.A.F. 2012).

89 Do Rosario Veiga, 568 F. Supp. 3d 367.

90 Al-Qaisi v. United States, 103 Fed. Cl. 439 (2012); Doe v. United States, 95 Fed. Cl. 546 (2010); Atamirzayeva v. United States, 524 F.3d 1320 (Fed. Cir. 2008); Atamirzayeva v. United States, 77 Fed. Cl. 378 (2007); Rosner v. United States, 231 F. Supp. 2d 1202 (S.D. Fla. 2002); Ashkir v. United States, 46 Fed. Cl. 438 (2000).

91 United States v. Ali, 71 M.J. 256 (C.A.A.F. 2012).

92 Do Rosario Veiga, 568 F. Supp. 3d 367.

93 Rosales v. Battle, 113 Cal. App. 4th Supp. 1178 (Ct. App. Dep't Super. Ct. 2003).

94 See Osorio-Martinez v. Attorney Gen., 893 F.3d 153, 166, 168 (3rd Cir. 2018); Castro v. United States Dep't of Homeland Sec., 835 F.3d 422, 434, 448 (3rd Cir. 2016).

95 Arbelaez v. Newcomb, 1 Fed. App'x. 1, 1 (D.C. Cir. 2001) (per curiam).

96 But see Lamont v. Woods, 948 F.2d 825, 834-35 (2d Cir. 1991) (relying on the analytical framework of Verdugo-Urquidez, looking to: (1) the operation and text of the provision; (2) history; and (3) likely consequences of applying it extraterritorially, but rejecting application of substantial connections because the Establishment Clause does not apply to "the people"); Lopez v. Mineta, No. B-01-208, 2002 U.S. Dist. 
"substantial connections" test to other constitutional provisions, but by far the most common is reliance on the Court's dicta that "[t]hese cases ... establish only that aliens receive constitutional protections when they have come within the territory of the United States and developed substantial connections with this country."97

Reliance on this dictum is inappropriate for three reasons. First, lower courts have treated this language as if it held that only aliens with substantial connections may claim the Constitution's protection. But that is not what Chief Justice Rehnquist wrote. In responding to claims by Verdugo-Urquidez that the Court had issued several decisions applying the Constitution to aliens, the majority held that those cases did no more than recognize rights for aliens with substantial ties. But it did not state that those were the only conditions upon which the Constitution could be invoked by aliens. Nor could it; in a line of cases under the Due Process Clause, it is the very lack of connections which prevent states from haling foreign corporations into their courts. ${ }^{98}$ Thus, if substantial ties were a necessary pre-condition to invoking constitutional protections, particularly the Due Process Clause, these cases would all have to be overturned.

Second, the "substantial connections" test itself arises from the use of the phrase "the people" in the Fourth Amendment. ${ }^{99}$ As noted above, the application of the substantial connections test makes no sense if the right claimed is not one promised to "the people." Thus, the dicta does not logically flow from the reasoning that precedes it.

Third, the cases the majority lumps together and dismisses do not stand for that proposition in the first place. While it is true that four of the cases dealt with resident aliens, ${ }^{100}$ two of them did not. ${ }^{101}$ Plyler $v$. Doe found that illegal aliens could claim the protection of the Equal Protection Clause. ${ }^{102}$ If the decisions by some lower courts that illegal aliens can never develop "substantial connections" 103 were

LEXIS 27264 (S.D. Tex. 2002) (refusing to extend Verdugo-Urquidez to Fifth Amendment claims of Due Process and Equal Protection); Nursing Home Pension Fund v. Oracle Corp., No. C01-00988 MJJ, 2007 U.S. Dist. LEXIS 49851 (N.D. Cal. 1997) (refusing to apply Verdugo-Urquidez to the self-incrimination clause of the Fifth Amendment).

97 See Castro v. United States Dep't of Homeland Sec., 835 F.3d at 448 (explicitly noting it was relying on dicta); Al-Marri v. Wright, 487 F.3d 160, 174 (4th Cir. 2007); Arbelaez v. Newcomb, 1 Fed. App'x. at 2; Veiga v. World Meteorological Org., 568 F. Supp. 2d at 374; United States v. Ali, 71 M.J. 256, 267 (C.A.A.F. 2012); Rosales v. Battle, 113 Cal. App. 4th at 1186.

98 See Daimler v. Bauman, 134 S. Ct. 746, 768 (2014); Goodyear Dunlop Tires Operations v. Brown, 564 U.S. 915, 920 (2011); J. McIntyre Machinery. v. Nicastro, 564 U.S. 873 (2011); Asahi Metal Indus. Co. Ltd. v. California, 480 U.S. 102, 122 (1987); Helicopteros Nacionales de Columbia v. Hall, 466 U.S. 408, 428 (1984); Insurance Corp. of Ireland v. Compagnie Des Bauxites de Guinee, 456 U.S. 694 (1982); Perkins v. Benguet Consol. Mining Co., 342 U.S. 437, 444 (1952).

99 See supra Part II.

100 Kwong Hai Chew v. Colding, 344 U.S. 590, 592 (1953); Bridges v. Wixon, 326 U.S. 135, 161 (1945); Wong Wing v. United States, 163 U.S. 228, 230 (1896); Yick Wo v. Hopkins, 118 U.S. 356, 358 (1886).

101 See Plyler v. Doe, 457 U.S. 202, 202 (1982) (dealing with illegal aliens); Russian Volunteer Fleet v. United States, 282 U.S. 481, 487 (1931) (dealing with a Russian corporation).

102 Plyler, 457 U.S. at 212.

103 See United States v. Boffil-Rivera, No. 08-20437-CR-GRAHAM/TORRES, 2008 U.S. Dist. LEXIS 84633 (S.D. Fla. 2008); United States v. Esparza-Mendoza, 265 F. Supp. 2d 1254, 1261 (D. Utah 2003). 
correct, this case could not possibly stand for the proposition that only aliens with substantial ties can claim constitutional protections. ${ }^{104}$ But even assuming those decisions are incorrect, Plyler did not differentiate between illegal aliens who had been here for years and those who had just crossed the border.

Russian Volunteer Fleet is even harder to square with the Chief Justice's pronouncement. A Russian corporation brought suit against the United States under the Fifth Amendment's Takings Clause, seeking recompense for two ships it had commissioned that were seized by the U.S. Shipping Board Emergency Fleet Corporation. ${ }^{105}$ So far as the record discloses, this shipbuilding contract was the only connection between the Russian corporation and the United States. There was no allegation that the Russian Volunteer Fleet had a physical presence in the United States, aside from its appearance, through counsel, in U.S. courts. Yet the Supreme Court held that if the Act of June 15, 1917-which authorized the seizure of the ships-denied the Russian corporation just compensation, it would be unconstitutional. ${ }^{106}$ Thus, the case does not stand for the proposition assigned to it.

In the case of the Takings Clause, the Court of Federal Claims has relied on a different rationale, one which explicitly rejects the textual basis of VerdugoUrquidez. ${ }^{107}$ The court summarized the arguments in favor of applying the "substantial connections" test as follows:

(1) "the 'substantial connections' rationale employed in VerdugoUrquidez, Johnson and other cases does not hinge on the specific language of any amendment, but rather on an overarching construct of the limited extraterritoriality of the Constitution, and, in particular, the Bill of Rights"; (2) "some courts and commentators have surmised that since the 'substantial connections' requirement bars the defensive assertion of constitutional rights, as a shield, by aliens haled into U.S. courts and subjected to criminal prosecution, it certainly must bar offensive assertions of constitutional rights, as a sword, by nonresident aliens voluntarily seeking redress in civil proceedings"; and (3) "although not always identified as such, the "substantial connections' requirement is well-evidenced in numerous cases involving takings claims." 108

None of these reasons stands up to scrutiny.

The first proposition cannot be squared with the majority's holding in Verdugo-Urquidez. The textual analysis is key to the creation of the "substantial connections" test, for the reasons outlined above. The test finds no other hook

104 The better reading is that Boffil-Rivera and Esparza-Mendoza are wrongly decided.

105 Russian Volunteer Fleet, 282 U.S. at 487.

106 Id. at 489 (holding that the only condition for claiming constitutional protection was the corporation's status as an "alien friend").

107 Ashkir v. United States, 46 Fed. Cl. 438, 443 (2000).

108 Atamirzayeva v. United States, 77 Fed. Cl. 378, 385 (2007) (summarizing Judge Allegra's holdings in Ashkir). 
anywhere within the Constitution. Ironically, Judge Allegra specifically notes that the Court relied on the textual exegesis of the phrase "the people" 109 and yet still applies the "substantial connections" test to a clause without the phrase. As for the structural argument, it runs counter the expressed will of the Framers to create a government of limited powers. Properly conceived, the Bill of Rights, despite its name, does not create any positive rights among the people. Rather, it provides further limits on the enumerated powers in the Constitution. Thus, while a narrow reading of the Articles may be appropriate, an expansive reading of the Bill of Rights is more true to the Founders' intentions.

The second proposition, while tempting, presupposes that the Bill of Rights cannot be used as a shield, which is not entirely correct. As noted above, foreign corporations routinely claim the shield of the Due Process Clause to prevent liability in U.S. courts when they lack sufficient connections to the United States. Furthermore, it is not clear to me that attempting to invoke the Fifth Amendment's Takings Clause would qualify as using the Bill of Rights as a sword-a claim only lies when the Federal Government first takes the affirmative step of taking property without compensation. Thus, even if it were correct to say that aliens should not be allowed to use the Bill of Rights as a sword, it would not justify denying the extraterritorial reach of the Takings Clause. Finally, even if Judge Allegra is correct and the Takings Clause should not always apply abroad, he does not explain why the "substantial connections" test is the appropriate way to determine if an alien has rights under this clause.

As for the last proposition, Judge Allegra found that the "substantial connections" test, although not explicitly named, underlies Takings Claims either through the citizenship or residency of the claimant, or the location of the property within the United States. While it is true that most claims under the Takings Clause meet at least one of these two tests, it ignores Turney $v$. United States, a decision in which the court recognized a claim by a citizen of the Philippines for a taking of radar equipment in that country. ${ }^{110}$ In fact, prior to Ashkir, the Court of Claims had never rejected a Takings Claim simply on the basis that both the property and the claimant had no ties to the United States. ${ }^{111}$

Simply put, there is no basis, in text or logic, for applying the reasoning of Verdugo-Urquidez, to clauses of the Constitution which do not use the term "the people." While some might argue that the term applies to the whole document by virtue of the fact that it is "the people" who ordain and establish the Constitution, this argument was implicitly rejected by the Verdugo-Urquidez majority when it distinguished the language of the Fifth and Sixth Amendments from that of the Fourth. Furthermore, Justice Kennedy, whose vote was necessary for the majority's

109 Ashkir, 46 Fed. Cl. at 443.

110115 F. Supp. at 458, 465 (1953).

111 Even if the substantial connections test did apply, it would seem that having your land or property taken by the U.S. government is a fairly substantial connection. 
reasoning, explicitly noted that the Due Process Clause of the Fifth Amendment would apply to the defendant in his concurring opinion. ${ }^{112}$

The misuse of the Verdugo-Urquidez analysis is particularly troubling for cases decided after the Supreme Court's decision in Boumediene v. Bush, which replaces the "substantial connections" test with the far more functional "impracticable and anomalous" test. ${ }^{113}$ Justice Kennedy discussed this test, borrowed from the controlling opinion in Reid v. Covert, in his Verdugo-Urquidez concurrence. ${ }^{114}$ In Boumediene, authored by Justice Kennedy, he secured five votes to make this test the appropriate means of determining if a specific constitutional provision applies abroad. Under this test, the Court rejects a "rigid and abstract rule" for determining where constitutional guarantees extend. ${ }^{115}$ Instead, it takes from the Insular Cases the lesson that "whether a constitutional provision has extraterritorial effect depends upon the "particular circumstances, the practical necessities, and the possible alternatives which Congress had before it' and, in particular, whether judicial enforcement of the provision would be 'impracticable and anomalous." 116 Tellingly, unlike Verdugo-Urquidez, who was a criminal defendant, the detainees at Guantanamo Bay were suspected of being illegal enemy combatants, waging war against the United States. The Court found that, per the terms of the lease with Cuba, the United States exercised "complete jurisdiction and control" of the naval base. ${ }^{117}$ The Court rejected the idea that formal notions of sovereignty governed the application of the Constitution abroad.

The Boumediene majority cites Verdugo-Urquidez only two times, both cites to Justice Kennedy's concurrence in that case. ${ }^{118}$ In deciding that alleged enemy combatants were protected by the Suspension Clause of the Constitution, the Boumediene majority did not cite their connections (or lack thereof) even once. The majority does not even acknowledge that the "substantial connections" test plays a role in determining the extraterritorial reach of the Constitution. This is particularly noteworthy in light of the fact that Justice Scalia cites to VerdugoUrquidez in his dissent for the proposition that "[t]here is simply no support for the Court's assertion that constitutional rights extend to aliens held outside U.S. sovereign territory." 119 The majority fails to respond to this point. ${ }^{120}$ While not a direct repudiation of Verdugo-Urquidez, Boumediene rejected the notion that a

112 United States v. Verdugo-Urquidez, 494 U.S. 259, 278 (1990) (Kennedy, J., concurring) (“All would agree, for instance, that the dictates of the Due Process Clause of the Fifth Amendment protect the defendant.").

113 Boumediene v. Bush, 553 U.S. 723, 759-60, 770 (2008).

114 Verdugo-Urquidez, 494 U.S. at 277-78 (Kennedy, J., concurring).

115 Reid v. Covert, 354 U.S. 1, 74 (1957) (Harlan, J., concurring).

116 Boumediene, 553 U.S. at 759 (quoting Reid, 354 U.S. at 74-75 (Harlan, J., concurring)).

117 Id. at 771.

118 Id. at 759, 760-62 (noting that if In re Ross were decided on citizenship grounds, Reid would have had to overturn it, which Justices Harlan and Frankfurter were unwilling to do).

119 Id. at 841 (Scalia, J., dissenting).

120 The Court does not even go so far as to state in a footnote that the test is inapplicable because Guantanamo Bay shares significant features of sovereign U.S. territory. 
substantial connection with the United States is a necessary precondition to invoke the protections of the Constitution.

Thus, it would appear that in the wake of Boumediene, lower courts should be applying the "impracticable and anomalous" test; but that has not been the case. ${ }^{121}$ The fact that lower courts continue to rely on the "substantial connections" test is further evidence that it is time the test was officially and explicitly replaced. What that replacement should look like is the subject of the next section.

\section{A Better Way to Conceptualize the Extraterritorial Fourth AMENDMENT}

There are two potential means of dealing with the above-identified problems: 1) more clearly define the "substantial connections test," and 2) scrap the test entirely and replace it with something else. I explore both possibilities in this part. While I conclude that replacing the "substantial connections" test is the best way to move forward, I also recognize that until the Supreme Court does so, lower courts may be constrained and have so far indicated an inclination to continue to embrace the test. Lower courts could rely on the intervening precedent in Boumediene to shift focus to the "impracticable and anomalous" test as opposed to the "substantial connections" test, while still maintaining fidelity to the hierarchical nature of the judiciary.

However, this would only solve half the problem. Under the "impracticable and anomalous" test, courts would apply the Fourth Amendment to all those present within the geographic boundaries of the United States, without regard to connections, as the Court held that the Suspension Clause applied in U.S.controlled Guantanamo Bay, despite the lack of connections any of the prisoners there had with the United States. On the other hand, Justice Kennedy already relied on this test to hold that those outside the United States are not entitled to the protections of the Fourth Amendment. ${ }^{122}$ This has the benefit of a clear rule, which courts and law enforcement can apply, but it fails to provide guidance on other Amendments. The test also fails to address the rights of U.S. citizens, and aliens with substantial connections, however defined, who are abroad.123 Given this, I propose a better way for lower courts to apply the test that provides more predictability for all parties.

\section{A. Defining "Substantial Connections"}

While Chief Justice Rehnquist found the term "the people" required the use of the "substantial connections test," the content of the test arises from the statement in Johnson v. Eisentrager that aliens are "accorded a generous and

121 See Osorio-Martinez v. Attorney Gen., 893 F.3d 153, 167, 177 (3rd Cir. 2018); United States v. PortilloMunoz, 643 F.3d 437, 443, 445 (5th Cir. 2011); United States v. Emmanuel, 565 F.3d 1324, 1331 (11th Cir. 2009); United States v. Alahmedalabdaloklah, No. CR-12-01263-PHX-NVW, 2017 U.S. Dist. LEXIS 102740 (D. Ariz. 2017); Doe v. United States, 95 Fed. Cl. 546, 567 (2010). 
ascending scale of rights as he increases his identity with our society."124 Thus, an alien's connection with the United States can be conceived of as a continuum running from absolutely no connections on one end to being a lawful permanent resident on the other. ${ }^{125}$ Somewhere on that continuum, an alien achieves sufficient connections to be considered one of "the people" entitled to the protections of the Fourth Amendment-but where?

In order to appropriately judge when someone has developed "substantial connections" courts should look to both the quality and quantity of connections. Certain connections, based on their quality, should automatically qualify as substantial for Fourth Amendment purposes. Others may need to be aggregated in order to achieve the level of "substantial connections." Based on the language of Verdugo-Urquidez, one such connection is voluntary presence in the United States. ${ }^{126}$ Since we are dealing with extraterritorial searches, presence seems like an odd factor to consider in the first place. But one lesson we can draw from this is that the voluntary nature of the connection is key.

Assuming presence is a requirement, for purposes of searches within the United States, voluntary presence should be enough. ${ }^{127}$ After all, Verdugo-Urquidez concerned itself only with the question of extraterritorial searches. It said nothing about searches, of aliens or others, within the borders of the United States. Given this, it seems odd to focus on presence at all.

Presence is voluntary even if it does not follow all the niceties of the Immigration and Nationality Act. All that is required is an independent decision to enter the country. Thus, even those aliens who lack appropriate documentation are capable of forming connections with this country that are every bit as substantial as those formed by citizens. The Supreme Court has recognized as much when it held that undocumented children were entitled to a public education. ${ }^{128}$ Furthermore, undocumented immigrants get married to citizens and have children who are citizens. Family ties are some of the most substantial ties a person can form. Nothing about an alien's immigration status affects the substance of these ties. Thus, having citizens within the close family network should be recognized as a substantial connection with the United States. ${ }^{129}$

124 For a study of the truth of this particular statement, see Won Kidane, Alien Spectrum Disorder: The Bill of Rights from Chinese Exclusion to Guantanamo, 20 BERKELEY LA RAZA L. J. 89 (2010).

125 The only more significant connection that can be had is citizenship, at which point the alien is no longer an alien.

126 Verdugo-Urquidez, 494 U.S. at 271.

127 Involuntary presence, such as being transported to the United States for trial, likely gives rise to other exceptions, such as searches incident to arrest or the sorts of safety searches that prisons and jails are allowed to conduct.

128 Plyler v. Doe, 457 U.S. 202, 230 (1982).

129 At the very least, such ties should create a rebuttable presumption of substantial connections. I can envision a scenario in which someone enters the United States, legally or not, impregnates a citizen and leaves the country, never to be seen again. Despite having a citizen child, presuming the baby is carried to term, this individual would not have a substantial connection with either the child or the country. In this case, ties to the family and ties to the country would be synonymous. 
Not every connection will be significant, or even necessarily contribute. For example, contrary to the Ninth Circuit's holding in Ibrahim v. Department of Homeland Security, it's not clear to me that attendance at a college should qualify. In most states, residents pay less tuition than out-of-state students. But nearly every state with differential tuition refuses to count time pursuing an education toward state residency. ${ }^{130}$ Thus, an alien who is only here to pursue an education likely cannot show a substantial connection to the United States or to any of them. This is not to say that education could not be part of a broader pattern, but taken alone they cannot create a substantial connection. In the context of an extraterritorial search, the alien would have severed ties with the United States by returning to their home country. ${ }^{131}$ Thus, these connections could be properly characterized as fleeting.

This brings up another question courts will have to deal with when making this determination-the age of the connection. Are connections durable? Is it enough to establish a connection once and then rely on it years later, even if those connections are not maintained? Let us assume that education qualified as a substantial connection; does someone who graduated in 1990 then returned home to a foreign country still qualify for Fourth Amendment protections today, or have they surrendered those connections? ${ }^{132}$ On the other hand, older connections that have been maintained are necessarily deeper than recently formed ones.

Based on the above, we can discern a framework for determining if an alien has formed substantial connections with this country so as to be entitled to the protections of the Fourth Amendment. By definition, this is going to be a case-bycase analysis and highly fact dependent. But one can lay out some markers to help guide courts faced with this difficult question, which is more than the Court did in Verdugo-Urquidez.

First, the court must determine if the alien's connections to the United States are voluntary. If the connections are not voluntary, that is the end of the inquiry and the Fourth Amendment does not apply. ${ }^{133}$ Second, the court should look to the depth or quality of the connection. Familial relationships are deep, as is the commitment to defending this country inherent in military service. Education alone is temporary and thus fleeting. Third, the court should look to the age of the

130 See, e.g., In-State Tuition and State Residency Requirements, FINAID, http://www.finaid.org/otheraid/stateresidency.phtml (last visited Feb. 1, 2020) ("Most states have established residency requirements designed to prevent out-of-state students who become residents incidental to their education from qualifying.").

131 This would not be the case during temporary breaks from schools, but an alien, who has completed (or abandoned) their education and returned home, lacks substantial connections to the United States.

132 These are not easy questions by any means. Under the Court's test, a U.S. citizen is automatically a member of "the people" even if they have lived overseas for years. So long as they maintain their citizenship, they would be protected by the Fourth Amendment. What's more, the child of two U.S. citizens who is born abroad and has never set foot in the United States would still qualify under the Court's test, because citizenship is the ultimate connection, but presence is not required to acquire citizenship if both parents are U.S. citizens.

133 This is consistent with the Court's holding in Verdugo-Urquidez that being prosecuted by the United States does not, in itself, provide a substantial connection. Verdugo-Urquidez, 494 U.S. at 271-72. 
connection. Older, sustained connections should be given more weight than recent ones. ${ }^{134}$ At the same time, even substantial connections may grow stale such that they no longer demonstrate ties to this country. A rough baseline of five years without maintaining a connection should present a rebuttable presumption that the alien no longer has sufficient ties.

Finally, courts should restrict these considerations solely to the Amendments that use the phrase "the people." The Fifth and Sixth Amendment, which use broader language, should be treated appropriately. Other clauses which do not contain the phrase "the people" do not limit themselves to the political community that requires a substantial connection to invoke their protections. Thus, the presumption in those cases should be that those provisions apply to aliens, regardless of their connections to the United States. Similarly, courts should presume that identical language requires identical treatment. Thus, the Second Amendment's protections should be co-extensive with the Fourth Amendment's protections.

With this new framework in place, courts can begin to create a consistent standard for determining when an alien has achieved a sufficient connection under Verdugo-Urquidez. This will still require ad hoc determinations and close cases. It is far easier is to establish a bright line, but this cannot be done by clinging to the "substantial connections" test. I offer such a bright line test in the next section.

\section{B. An Alternative Framework}

Far better than even a well-defined $a d$ hoc test is a clear bright line test-one that asks a single question with an easily ascertained answer: is the search conducted by U.S. agents engaged in enforcing U.S. criminal laws? This test focuses not on who is being searched, but rather who is doing the searching. I agree with the mutuality theory relied upon by Justice Brennan ${ }^{135}$ that there can be no valid exercise of U.S. government power without a corollary extension of the limits on that power. ${ }^{136}$

Under this view, the Constitution does not apply to some "undefined, limitless class" of people, a concern of Justice Kennedy. ${ }^{137}$ Instead, it is a very well defined and delimited population: U.S. agents engaged in enforcement of the criminal laws of the United States outside our borders. ${ }^{138}$ This would not overly

134 This is not a hard and fast rule. The birth of a U.S. citizen child will be substantial even if the child is recently born, provided the alien shows an intent to be involved in the child's life.

135 Verdugo-Urquidez, 494 U.S. at 297 (Blackmun, J., dissenting).

136 An alternative formulation is that the Fourth Amendment's reach is co-terminus with the application of United States sovereign power. Thus, it is the government agents conducting the search who carry the Fourth Amendment with them. A similar argument was made by Koff, supra note 9, at 488-89.

137 Verdugo-Urquidez, 494 U.S. at 275 (Kennedy, J., concurring).

138 I do not here address the thornier question of whether those exercising military power would be limited by the Fourth Amendment. Courts have traditionally held that the Fourth Amendment does not apply on the field of battle, although it has been held to apply to the search of a U.S. citizen's apartment by military forces in occupied Vienna. See Best v. United States, 184 F.2d 131 (1st Cir. 1950). In that case, the Court concluded the search was reasonable. Furthermore, in Boumediene, the Court held that the Suspension 
extend current law. Virtually all criminal prosecutions within U.S. boundaries are currently covered by the Fourth Amendment, ${ }^{139}$ as are searches of U.S. citizens abroad, when conducted by U.S. agents or with their substantial participation. ${ }^{140}$ The extension I favor is actually relatively modest and extremely straightforward. Furthermore, it would respect the underlying nature of the Constitution as a grant of limited powers to the Government. It would also be consistent with the interpretation of other criminal procedure amendments, such as the Fifth and Sixth Amendments, which apply to all criminal defendants regardless of citizenship and location. ${ }^{141}$

Alternatively, one could also extend the protections against unreasonable search and seizures to aliens abroad as a component of Due Process, as protected by the Fifth Amendment. Outside of the war context, the Supreme Court has never held that the Due Process Clause does not apply to aliens outside the United States. ${ }^{142}$ Justice Kennedy noted in his concurrence that no one would dispute the application of the Due Process Clause to Verdugo-Urquidez himself. ${ }^{143}$

The Supreme Court has relied on due process to extend other protections of the Bill of Rights in other contexts. The most obvious of these is the incorporation of the Bill of Rights to the states via the Due Process Clause of the Fourteenth Amendment. ${ }^{144}$ The Amendments do not apply to the states of their own force, but the Court has held that the Due Process Clause contains those rights and applies

Clause applied to suspected enemy combatants held in U.S. custody by military officials. Boumediene v. Bush, 553 U.S. 723, 745-46 (2008).

139 It is true that, due to a series of judicial decisions, there are often exceptions and other hurdles that make a remedy unavailable. However, the lack of a remedy is no excuse for failing to recognize the application of constitutional rights, particularly when dealing with judicially-created exceptions. The law evolves, and an exception recognized today may fade in the future. In that case, having access to the right would be vitally important, even if there is no current practical difference.

140 See cases cited, infra, notes 152-159.

141 Although there are not many criminal trials conducted under the auspices of United States sovereign power that take place outside of the territory of the United States, the United States Court for Berlin held that foreign nationals, tried in Berlin for violations of U.S. law, were entitled to constitutional rights including the right to a trial by jury. See U.S. v. Tiede, 86 F.R.D. 227 (D. Berlin 1979). This finding was made in spite of the fact that Tiede was tried in 1979 and the Federal Republic of Germany assumed full sovereign control of its territory on May 5, 1955. Id. at 232.

142 On the contrary, where foreign corporations are concerned, the Court has consistently extended the protections of the Fourteenth Amendment's Due Process Clause. See generally Daimler, AG v. Bauman, 134 S. Ct. 746 (2014); J. McIntyre Mach. Ltd. v. Nicastro, 564 U.S. 873 (2011); Goodyear Dunlop Tires Operations v. Brown, 564 U.S. 915 (2011); Asahi Metal Indus. Co. v. Superior Ct., 480 U.S. 102 (1987); Helicopteros Nacionales de Columbia v. Hall, 466 U.S. 408 (1984); Ins. Corp. of Ireland v. Compagnie Des Bauxites de Guinee, 456 U.S. 694 (1982); Perkins v. Benguet Consol. Mining Co., 342 U.S. 437 (1952).

143 Verdugo-Urquidez, 494 U.S. at 278 (Kennedy, J., concurring).

144 See generally McDonald v. Chicago, 560 U.S. 742 (2010) (right to bear arms); Benton v. Maryland, 395 U.S. 784 (1969) (double jeopardy); Duncan v. Louisiana, 391 U.S. 145 (1968) (trial by impartial jury); Robinson v. California, 370 U.S. 660 (1962) (protection from cruel and unusual punishment); Mapp v. Ohio, 367 U.S. 643 (1961) (unreasonable search and seizure); Everson v. Bd. of Educ., 330 U.S. 1 (1947) (incorporating Establishment Clause); Near v. Minnesota, 283 U.S. 697 (1931) (freedom of the press). These cases are merely a representative sample. See also Palko v. Connecticut, 302 U.S. 319 (1937) for the test to determine which rights are so fundamental as to require incorporation. 
them to the states. ${ }^{145}$ The Court has long held that the two Due Process Clauses are to be read to have the same content; if the Due Process Clause of the Fourteenth Amendment contains these rights, then the Due Process Clause of the Fifth Amendment must contain them also. ${ }^{146}$

The Court has repeatedly said that the Due Process Clause should be read expansively, and "conveys neither formal nor fixed nor narrow requirements. It is the compendious expression for all those rights which the courts must enforce because they are basic to our free society." 147 Tellingly, the Court used this language when deciding that the Fourth Amendment applied against the states. In Wolf $v$. Colorado, the Supreme Court held that the protections of the Fourth Amendment were "basic to a free society." 148 Justice Jackson famously described uncontrolled search and seizure as "one of the first and most effective weapons in the arsenal of every arbitrary government."149 A majority of the Court adopted this view in Almeida-Sanchez $v$. United States, when it held that even an illegal alien within the United States could claim the protections of the Fourth Amendment. ${ }^{150}$ It makes perfect sense to extend the Fourth Amendment, recognized as fundamental to the concept of ordered liberty, to any against whom the United States wishes to extend its criminal process.

Regardless of whether the Court extended the right under the Fourth or Fifth Amendment, it would be left with an important question: what would such application look like? Justice Kennedy identified three pragmatic problems with applying the warrant requirement overseas: (1) the lack of a magistrate authorized to issue such a warrant, (2) the differing conceptions of privacy in foreign countries, and (3) the need to cooperate with foreign officials. ${ }^{151}$ Congress could fix the first concern, though it has failed to take any action to do so. If the Court were to adopt a view of the Fourth Amendment as traveling with federal agents, the second concern would not be implicated; privacy conceptions of foreign countries would not matter-the appropriate question would be whether the search complied with U.S. conceptions of privacy. While the need to cooperate with foreign officials can of course be important, such international cooperation cannot overrule the

145 See Wolf v. Colorado, 338 U.S. 25 (1949) (noting that guarantees of the Bill of Rights are applied to the states via the Fourteenth Amendment's Due Process Clause).

146 See generally Heiner v. Donnan, 285 U.S. 312, 326 (1932) (holding that restraint imposed upon legislation by the Due Process Clauses of the Fourteenth and Fifth Amendments is the same); Twining v. New Jersey, 211 U.S. 78, 100, 101 (1908) (holding that because the two amendments use identical words, they should be interpreted identically); Hibben v. Smith, 191 U.S. 310, 325 (1903) ("The Fourteenth Amendment, it has been held, legitimately operates to extend to the citizens and residents of the states the same protection against arbitrary state legislation affecting life, liberty, and property as is offered by the Fifth Amendment against similar legislation by Congress ....").

147 Wolf v. Colorado, 338 U.S. at 27.

148 Id.

149 Brinegar v. United States, 338 U.S. 160, 180 (1949) (Jackson, J., dissenting).

150 Almeida-Sanchez v. United States, 413 U.S. 266, 274-75 (1973).

151 Verdugo-Urquidez, 494 U.S. at 278 (Kennedy, J., concurring). Neither the Verdugo-Urquidez majority, nor Justice Kennedy, addressed how to apply the Warrant Clause to extraterritorial searches involving aliens with substantial connections. 
requirements of the Constitution. ${ }^{152}$ Furthermore, if the United States deems such cooperation to be vital, it may still engage in such cooperation-it just may not rely on the fruits of an illegal search in a U.S. prosecution.

While one might expect Congress to swiftly create a magistrate authorized to issue foreign warrants if the Court were to vigorously enforce such a requirement on extraterritorial searches, such an extreme step is unnecessary. In addition to requiring a warrant, the Fourth Amendment also contains the reasonableness requirement, which has played an ever-larger role in recent jurisprudence. ${ }^{153}$ Both Justice Stevens and Justice Blackmun supported this approach in their respective Verdugo-Urquidez opinions. ${ }^{154}$ Assessing reasonableness is a familiar judicial function. The question becomes when to apply the reasonableness requirement. Even with my proposed test there can be a question of whether U.S. agents were the ones conducting the search, particularly in a situation like Verdugo-Urquidez, where they work closely with local authorities. Thankfully, lower courts already have vast experience in this area.

A host of lower court cases have addressed the proper scope of Fourth Amendment protections in relation to searches of U.S. citizens conducted abroadparticularly the use in U.S. courts of evidence obtained during such searches. ${ }^{155}$ The most common methodological tool used by these courts is the joint venture test. ${ }^{156}$ This test determines whether agents of the United States had "sufficient participation" in the search to justify applying the exclusionary rule. ${ }^{157}$ If U.S.

152 See Medellin v. Texas, 552 U.S. 491 (2008). There, the Court held that the president could not prevent Texas from carrying out the execution of a Mexican national who had been denied his rights under Article 36 of the Vienna Convention on Consular relations, even in the face of a ruling from the International Court of Justice that the United States was required to comply. The Court held that since the Vienna Convention was not self-executing, only Congress could require enforcement, a decision that caused international friction.

153 See Ohio v. Robinette, 519 U.S. 33, 39 (1996) ("We have long held that the "touchstone of the Fourth Amendment is reasonableness." (quoting Florida v. Jimeno, 500 U.S. 248, 250 (1991)); Riley v. California, 134 S. Ct. 2473 (2014) ("As the text makes clear, "the ultimate touchstone of the Fourth Amendment is "reasonableness."”" (quoting Brigham City v. Stuart, 547 U.S. 398, 403 (2006)).

154 Both Justices believed the appropriate question was whether the search was reasonable. Justice Stevens believed it was, and Justice Blackmun would have remanded the case to the lower courts to examine the question in the first instance. Compare Verdugo-Urquidez, 494 U.S. at 279 (Stevens, J., concurring), with id. at 297-98 (Blackmun, J., concurring).

155 See generally United States v. Stokes, 726 F.3d 880, 886 (7th Cir. 2013) (foreign search conducted jointly by U.S. and foreign agents); In re Terrorist Bombings of U.S. Embassies in E. Afr. (Fourth Amendment Challenges), 552 F.3d 157, 160 (2d Cir. 2008) (foreign search conducted by U.S. agents); United States v. Maturo, 982 F.2d 57, 59 (2d Cir. 1992) (foreign search conducted by foreign agents); United States v. Peterson, 812 F.2d 486, 489 (9th Cir. 1987) (foreign search conducted jointly by U.S. and foreign agents); United States v. Demanett, 629 F.2d 862, 865 (3d Cir. 1980) (foreign search conducted by U.S. agents); United States v. Rose, 570 F.2d 1358, 1360 (9th Cir. 1978) (foreign search conducted by foreign agents); United States v. Morrow, 537 F.2d 120, 130 (5th Cir. 1976) (same); Brulay v. United States, 383 F.2d 345, 347-48 (9th Cir. 1967) (foreign search conducted by foreign agents); United States v. Grisby, 335 F.2d 652, 653-54 (4th Cir. 1964) (foreign search conducted by U.S. agents). For an examination of two different searches by different sets of agents and their effects on the Fourth Amendment analysis, see United States v. Barona, 56 F.3d 1087, 1089-90 (9th Cir. 1995).

156 E.g., United States v. Peterson, 812 F.2d 486, 490 (9th Cir. 1987).

157 Id. 
agents did not substantially participate, then exclusion of seized evidence is not warranted because exclusion has no deterrent effect on foreign law enforcement. ${ }^{158}$ This joint venture test has been used both before Verdugo-Urquidez ${ }^{159}$ and after. ${ }^{160}$

My approach does not suggest the wholesale adoption of the joint venture test since I believe part of the test is flawed. As conceptualized, the test holds that if the U.S. agents did substantially participate in the search, the court will examine the law of the foreign country to determine if the search was reasonable. ${ }^{161}$ Under my conception, this is an inappropriate inquiry. The proper basis for determining reasonability is U.S. law. Thus, an examination of foreign law is unnecessary when U.S. agents are conducting the search or are substantially involved. As noted above, applying the exclusionary rule to searches conducted entirely by foreign entities does not serve any deterrent effect. Thus, if, for example, the British government conducted a search of a British citizen, found evidence of a violation of U.S. law, and turned that evidence over to U.S. federal agents for prosecution, the Fourth Amendment is not implicated. One could imagine that this might lead to the outsourcing of searches of foreign lawbreakers to foreign governments. However, two considerations mitigate against this concern.

First, under the joint venture test as currently practiced, U.S. courts only care about compliance with foreign law if U.S. agents are substantially involved in the search. This has not led to outsourcing U.S. criminal investigations of U.S. citizens abroad. Second, in addition to the joint venture test, courts have also recognized exceptions for foreign searches which "shock the [judicial] conscience" regardless of who has carried them out. ${ }^{162}$ Thus, even in cases where countries have much lower standards for searches than the United States, if the behavior of foreign agents is egregious, U.S. courts will recognize them as antithetical to the very idea of due process. The "shocks the conscience" test thus serves as a judicial backstop against the most outrageous actions by foreign governments.

Overall, there is much to recommend the modified joint venture test. It provides a clear framework for when the Fourth Amendment would apply: if the search is conducted by foreign agents on their own initiative, or with little U.S.

158 Very few of the cases involved such a fact pattern. See, e.g., United States v. Baboolol, No. 05-CR-215, 2006 WL 1674480, at*2-3 (E.D. Wis. June 16, 2006) (challenging search of Canadian citizen's Canadian residence by Canadian police).

159 See, e.g., United States v. Morrow, 537 F.2d 120, 140 (5th Cir. 1976) (citing Stonehill v. United States, 405 F.2d 738, 743 (9th Cir. 1968)).

160 See United States $v$. Stokes, 726 F.3d 880, 890-91 (7th Cir. 2013) (citing United States v. Barona, 56 F.3d 1087, 1091 (9th Cir. 1994)); United States v. Barona, 56 F.3d 1087 (9th Cir. 1994). But cf. United States v. Vilar, No. S305CR621KMK, 2007 WL 1075041, *54 \& n.34 (S.D.N.Y. Apr. 4, 2007) (noting that the Second Circuit had not adopted the joint venture doctrine, but finding applicability of the Fourth Amendment when cooperation with foreign law enforcement "is designed to evade constitutional requirements applicable to American officials").

161 Peterson, 812 F.2d at 490.

162 See, e.g., United States v. Rose, 570 F.2d 1358, 1362 (9th Cir. 1978) (alternation in original) (citing Birdsell v. United States, 346 F.2d 775, 782 n.10 (5th Cir. 1965).). Unlike a Fourth Amendment violation, which the Court held occurs at the time of the search, the "shocks the conscience" test is an exercise of the Fifth Amendment's Due Process Clause and a violation occurs at trial. Koff, supra note 9, at 443 n.20. 
involvement, the Fourth Amendment does not apply. ${ }^{163}$ Regardless of the reach of the Fourth Amendment, it certainly does not bind non-U.S. agents. Numerous courts have pointed out that the exclusionary rule has no deterrent effect on such agents. If the search is a true joint venture between the United States and foreign agents or if U.S. agents conduct searches on their own in foreign countries, then the Fourth Amendment does apply. ${ }^{164}$

The modified joint venture test does not implicate the three practical concerns identified by Justice Kennedy, if properly applied. First, there is no need for a magistrate to issue an ex ante ruling on reasonableness. Aliens may raise challenges to searches conducted, in whole or in part, by U.S. agents in motions in limine seeking to exclude illegally seized evidence. Second, cooperation with foreign officials is assumed under the joint venture test. As for the concern about differing conceptions of privacy, the modified joint venture test proposed in this Article looks to U.S. conceptions of privacy when U.S. agents are involved. Even in a case where the foreign agents act alone and the defendant argues their conduct "shocks the conscience," courts would not be called upon to delve into foreign law because the "shocks the conscience" test is based on U.S. standards. 165

This only leaves the question of searches conducted on the high seas. These types of searches are typically conducted solely by U.S. agents under statutes such as the Maritime Drug Law Enforcement Act. ${ }^{166}$ In this circumstance, U.S. magistrates are well acquainted with making determinations of reasonableness in the absence of a warrant. They should ask whether the U.S. agents had probable cause to conduct the search and seizure. Far from being unusual, this sort of post hoc review of probable cause on the high seas continues a tradition that has been in place since the Founding. ${ }^{167}$ The modified joint venture test is actually more useful here because there is no local law to apply on the high seas.

The test proposed in this Article would have numerous advantages over the substantial connections test. First, it is logically consistent and supported by the text and structure of the Constitution, recognizing that the Fourth Amendment is a check on government power to safeguard pre-existing rights held by all people. Second, it provides guidance to the lower courts that the substantial connections

163 Lower courts have vast experience applying the joint venture test. Koff, supra note 9, at 442 n.19. This experience has only grown since 1994 .

164 There may be cases where the deterrent effect of the exclusionary rule plays no part, such as when the government wants the information for intelligence purposes rather than criminal justice. In those cases, aliens are in no worse shape than their American counterparts subjected to such searches. Absent congressional action to allow a damages remedy, even U.S. citizens are unlikely to win a Bivens action against federal agents.

165 To be sure, a court could look to see if the search by foreign agents complies with foreign law as a measure of whether their behavior "shocks the conscience." Courts routinely look to foreign law in deciding whether foreign searches of U.S. citizens are reasonable. See supra note 155. Additionally, courts routinely apply foreign law in other contexts, such as contracts. There is no reason why discerning foreign search and seizure law should be any more difficult, especially when courts make clear that it is up to the parties to provide evidence of the substance of foreign law.

166 Maritime Drug Law Enforcement Act, 46 U.S.C. $§ \S 70501-70508$ (2018).

167 See Little v. Barreme, 6 U.S. 170, 177-178 (1804); Talbot v. Seeman, 5 U.S. 1, 31-32 (1801). 
test severely lacks. Rather than trying to determine if an alien has enough ties to qualify for the protections of the Fourth Amendment, it provides a bright line rule that when U.S. agents conduct a search, the Fourth Amendment travels with them, regardless of where the search occurs. While there may be some disputes at the boundaries of sufficient participation, long experience in the lower courts shows that this is a much more manageable standard, which has not led to wildly differing interpretations. ${ }^{168}$ Finally, the baseline rule that the Constitution travels with U.S. agents can be expanded to the interpretation of other amendments without doing damage to the text of those amendments. ${ }^{169}$ Thus, the proposed rule solves the problems caused by the substantial connections test without imposing undue costs on the federal judiciary.

The Verdugo-Urquidez majority identified two practical concerns with extending the Warrant Clause of the Fourth Amendment outside the United States: 1) the rule adopted by the court of appeals would apply to both law enforcement and other foreign policy operations abroad which might result in searches or seizures, and 2) the majority feared the specter of subjecting U.S. agents to Bivens liability for their actions abroad. ${ }^{170}$ Subsequent developments have undercut these concerns.

Regarding the application of the Fourth Amendment to military actions, there are three responses. First, the Court has long recognized exceptions to the Fourth Amendment, particularly where the foreign affairs powers of the United States are concerned. As one example, the Court has long recognized the special needs doctrine which provides an exception to the Fourth Amendment where law enforcement is not the primary purpose. ${ }^{171}$ Thus, even if the Court adopted a rule that the Fourth Amendment applied everywhere, recognized exceptions to the Warrant Clause would travel with it.

Second, courts have applied the Fourth Amendment's reasonableness requirement to military searches without ill effect. ${ }^{172}$ This argument is also undercut by the U.S. military's own regulations. As Justice Brennan pointed out in

168 Furthermore, in those cases where the courts determine that aliens have substantial connections, they would still be required to conduct the joint venture test for searches conducted abroad since such aliens have rights. My proposed test would merely eliminate the first stage of the inquiry.

169 My intention is merely to address the specific question asked by Verdugo-Urquidez. However, I recognize that lower courts have vastly expanded the reach of the substantial connections test, so any proposed replacement must be at least as capable of application to other provisions while doing substantially less damage to them.

170 United States v. Verdugo-Urquidez, 494 U.S. 259, 273-74 (1990).

171 See New Jersey v. T.L.O., 469 U.S. 325, 351 (1985) (Blackmun, J., concurring); United States v. Kincade, 379 F.3d 813, 823-24 (9th Cir. 2004) (collecting cases). For a history of the special needs doctrine and its application to foreign affairs and national security, see Sarah Fowler, Note, Circumventing the Constitution for National Security: An Analysis of the Evolution of the Foreign Intelligence Exception to the Fourth Amendment's Warrant Requirement, 4 U. Miami Nat'L Security \& ARMed Conflict L. Rev. 207, 215-16 (2014). This exception applies when complying with the warrant requirement would be impractical.

172 See Best v. United States, 184 F.2d 131, 138-39 (1st Cir. 1950). Best, a U.S. citizen, broadcast Nazi propaganda during the war. After the war ended, he was arrested by Occupation Forces and his Vienna apartment was searched. The First Circuit assumed the Fourth Amendment applied and conducted a reasonableness inquiry, determining that it in the circumstances of the search-occurring in an occupied country under military government, deemed necessary by military commanders - the search was not unreasonable. 
his dissent, Department of the Army regulations in place at the time of VerdugoUrquidez required that the Army seek a judicial warrant from a U.S. court whenever the Army sought "to intercept the wire or oral communications of a person not subject to the Uniform Code of Military Justice outside of the US and its territories." 173 Thus, even the military, about which the majority was concerned, did not object to the warrant requirement on some of its activities.

Finally, the Court could create a new exception to the Fourth Amendment for military activities specifically. The Court was concerned about the breadth of the lower court's rule, but it acted as if it were faced with the Hobson's choice of applying the Fourth Amendment to all actions outside the United States or to none of them. In fact, the Court regularly recognizes exceptions to the Fourth Amendment, largely based on practicality, which it could narrow solely to the military context.

The second concern identified by the Court—subjecting U.S. agents abroad to Bivens liability—has been overtaken by subsequent legal developments. In the quarter century since Verdugo-Urquidez was decided, the Court has all but abandoned Bivens as a viable option outside of the very specific contexts in which a remedy has previously been recognized. ${ }^{174}$ Courts have consistently rejected the application of Bivens remedies to any actions taking place outside the U.S., finding "special factors counseling hesitation." 175 While the Court acknowledged that such special factors might exist, it was concerned about the "case-by-case adjudications concerning the availability of such an action." 176 However, the consistent rejection of new Bivens remedies has proven this concern is nothing more than a paper tiger. Therefore, the Court's practical concerns with extending the Fourth Amendment to aliens have been alleviated. ${ }^{177}$

\section{CONCLUSION}

Nearly thirty years ago, the Court addressed the extraterritorial application of the Fourth Amendment for the first—and so far, last_-time. There were numerous problems with the majority's holding, which have only been borne out over the last three decades. With an increased interest in the rights of aliens coming before the lower courts, the time has come to rethink the rationale of the decision.

The current rationale provides little guidance to lower courts and has been applied to areas of law where it is wholly inappropriate. For those reasons, it is time

173 Verdugo-Urquidez, 494 U.S. at 296 n.14 (Brennan, J., dissenting).

174 See Ziglar v. Abbasi, 137 S. Ct. 1843, 1869 (2017) (denying Bivens remedy to aliens held in U.S. prison after September 11 attacks); Ashcroft v. Iqbal, 556 U.S. 662, 675 (2009) ("Because implied causes of action are disfavored, the Court has been reluctant to extend Bivens liability 'to any new context or new category of defendants." (quoting Corr. Servs. Corp. v. Malesko, 534 U.S. 61, 68 (2001))).

175 See Meshal v. Higgenbotham, 804 F.3d 417, 425-26 (D.C. Cir. 2015); Vance v. Rumsfeld, 701 F.3d 193, 199 (7th Cir. 2012).

176 Verdugo-Urquidez, 494 U.S. at 274.

177 It is also unclear why the Court was concerned with such liability arising toward aliens with no ties to the United States when an alien with substantial ties would have a viable Bivens claim. The Court fails to explain why the existence of ties would alleviate its concerns. 
to replace it with a rationale that makes sense. The proper way to conceptualize the extraterritorial Fourth Amendment is to rely on a method courts have been using for over fifty years: the modified joint venture test. Searches conducted wholly by foreign law enforcement would not be covered by the Fourth Amendment; those conducted with substantial involvement of U.S. law enforcement would be subject to review under the Fourth Amendment's command of reasonableness. The conceptions of reasonableness are defined by the U.S. Constitution, which travels with U.S. agents wherever and against whomever they may act. These principles are familiar to courts, have a long pedigree in judicial precedent, and appropriately balance the interests of law enforcement and the rights of individuals, while also taking into account the practical problems with demanding extraterritorial warrants. If the Court were to adopt this reasoning, it would go a long way to cleaning up this area of law. 